\title{
$\mathrm{Ti}-\mathrm{Fe}$ 合金の微細組織と機械特性に及ぼす $\mathrm{Al}$ 添加の影響
}

\author{
竹元 嘉 利 ${ }^{1}$ \\ 越智昌宏 1 ,* \\ 瀬沼武秀1 \\ 高田 $\quad$ 潤1 $\quad$ 清水一郎 $1 \quad$ 松木一弘 ${ }^{2}$ \\ 1岡山大学大学院自然科学研究科 \\ 2 広島大学大学院工学研究科
}

J. Japan Inst. Metals, Vol. 76, No. 5 (2012), pp. 332-337

(C) 2012 The Japan Institute of Metals

\section{Influence of Al Addition on Microstructures and Mechanical Properties of Ti-Fe Alloys}

\author{
Yoshito Takemoto ${ }^{1}$, Masahiro Ochi ${ }^{1, *}$, Takehide Senuma ${ }^{1}$, \\ Jun Takada ${ }^{1}$, Ichiro Shimizu ${ }^{1}$ and Kazuhiro Matsugi ${ }^{2}$ \\ ${ }^{1}$ Graduate School of Natural Science and Technology, Okayama University, Okayama 700-8530
${ }^{2}$ Graduate School of Engineering, Hiroshima University, Higashihiroshima 739-8527
}

The influence of $\mathrm{Al}$ content on the evolution of microstructures and mechanical properties of $\mathrm{Ti}-x \mathrm{Fe}-y \mathrm{Al}$ alloys quenched from a $\beta$ field was investigated via hardness measurements, tensile tests, scanning electron microscopy (SEM) equipped with electron back scattering pattern (EBSP) analyzer, and conventional transmission electron microscopy (TEM). The hardness of $\mathrm{Ti}-(3-6) \mathrm{Fe}-y \mathrm{Al}$ decreased remarkably on addition of $1 \% \mathrm{Al}$. In comparison to binary alloys, the maximum hardness decrease was achieved in $\mathrm{Ti}-4 \mathrm{Fe}-1 \mathrm{Al}$. The hardness of $\mathrm{Ti}-4 \mathrm{Fe}-y \mathrm{Al}$ decreased with increasing $\mathrm{Al}$ content up to around $5 \%$, reaching a minimum, then gradually increased. Though all of the $\mathrm{Ti}-3 \mathrm{Fe}-y \mathrm{Al}$ alloys showed the martensite structure, $\mathrm{Ti}-4 \mathrm{Fe}-y \mathrm{Al}$ showed a structural change of $\beta+\omega \rightarrow \beta+\omega+$ martensite $\rightarrow \beta+\omega$ with increasing $\mathrm{Al}$ content. Consequently, $\mathrm{Ti}-4 \mathrm{Fe}-7 \mathrm{Al}$ had the lowest density in the $\beta$-type alloys equivalent to that of Ti-6Al-4V. The ratio of reciprocal distance $d^{*}{ }_{0002 \omega} / d_{222 \beta}^{*}$ on selected-area diffraction (SAD) pattern, which is often used as an indicator of $\{332\}\langle 113\rangle$ twin formation, was nearly constant up to $5 \% \mathrm{Al}$ of $\mathrm{Ti}-4 \mathrm{Fe}-y \mathrm{Al}$, but decreased over $6 \% \mathrm{Al}$. The tensile tests of both $\mathrm{Ti}-4 \mathrm{Fe}-5 \mathrm{Al}$ and $\mathrm{Ti}-4 \mathrm{Fe}-7 \mathrm{Al}$ showed ductility. The deformation behavior of $\mathrm{Ti}-4 \mathrm{Fe}-5 \mathrm{Al}$ producing strain-induced martensite resembled that of $\mathrm{Ti}-8 \mathrm{Mo}$. On the other hand, Ti- $4 \mathrm{Fe}-7 \mathrm{Al}$ was deformed by a coarse slip of $\{112\}\langle 111\rangle$ in the same manner as Ti-20Mo, and the SAD pattern analysis revealed that the diffuse reflection of the $\omega$ phase in the non-deformed area turned into the spots at the deformation band. It was suggested that $\mathrm{Al}$ behaves as a $\beta$ stabilizer element when added to the lowest $\beta$ alloy and is available for weight saving, while maintaining the $\beta$ structure.

(Received January 26, 2012; Accepted February 13, 2012; Published May 1, 2012)

Keywords: $\beta$-stabilizer, $\alpha$-stabilizer, ubiquitous element, lightweight alloy, omega phase, martensite

\section{1. 緒言}

$\beta$ 型 $\mathrm{Ti}$ 合金は高強度, 加工性, 耐食性に優れた構造材料 であるとともに，低ヤング率，形状記憶など機能性に富んだ 合金として知られている1-6). しかし, Mo, Ta, V, Nb といっ た高価な添加元素を多く必要とし, 素材コスト高に加えて軽 量性が損なわれるのが欠点である. 一方, Ti 合金の代表格 でもある Ti-6Al-4V は強度・延性バランスに優れ純 $\mathrm{Ti}$ より 軽量であるが， $\alpha+\beta$ 型合金であるため冷間加工性が非常に 悪く, 熱間により成形するため加工コストが高くなる. また Vが非常に高価で毒性があるため生体への使用にはその為 害性が懸念されている。もし $\beta$ 型 $\mathrm{Ti}$ 合金が安価で軽量かつ 冷間加工性に優れるものであれば，その利用は飛躍的に増加

* 岡山大学大学院生 (Graduate Student, Okayama University)
すると思われる。

一方で近年の $\mathrm{Ti}$ 資源の枯渴問題や希少金属の高騰に伴 い, 安価な元素で代替した合金開発が進められている7,8). 安価な元素としては $\mathrm{Fe}$ や $\mathrm{Al}$ 等が考えられる. $\mathrm{Fe}$ は $\beta$ 共析 型元素でわずか $4 \%$ 以上の添加で $\beta$ 相を安定化させることが できるため軽量化にも効果的である ${ }^{9)}$.しかし Ti-Fe 合金は Ti-Mo p Ti-V などの $\beta$ 安定型合金と比べ, 加工性が非常 に悪いことからこれまであまり研究されてこなかった。一般 に $\beta$ 型 Ti 合金の变形様式は高組成合金ですべり変形, 低組 成合金で $\{332\}\langle 113\rangle$ 双晶変形することが知られており，特 に $\{332\}$ 双晶は加工硬化を伴って $50 \%$ もの破断伸びが得られ 工業的に非常に有用である10). また $\{332\}$ 双晶の生成条件は $\beta$ 領域からの焼入れ材において, 整合性の高い $\omega$ 相が出現 する合金組成で形成され, 花田らによると電子線回折の $d^{*}{ }_{0002 \omega} / d^{*}{ }_{222 \beta}$ が 0.66 以上の整合度が $\{332\}$ 双晶形成の条件 としている11-14)。この条件は同時に $\omega$ 相が最も多く生成す 
る比較的硬い合金で $\{332\}$ 双晶が形成されることを意味する. $\mathrm{Ti}-\mathrm{Fe}$ に限らず Ti-Co や Ti-Ni でも同様な傾向を示すが， そのような条件では硬さが異常に高い $(500 \mathrm{Hv} \sim)$ のが特徵 である ${ }^{9)}$.このため $\mathrm{Ti}-\mathrm{Fe}$ 合金では脆性破壊を示し構造材料 としては不適である。但し非常に限定された組成 ( $\mathrm{Ti}-$ $4.5 \mathrm{Fe})$ では $\{332\}$ 双晶が形成することが報告されている が14)，その機械特性までは知られていない，以上のことか ら Ti-Fe 合金の実用化には機械特性の改善が必須であり, 第 3 元素を考慮する必要がある. 本研究では Ti-Fe 合金に $\alpha$ 安定化元素である Al を添加し, その微細組織, 硬さ測定 を行い Ti-Fe 合金の機械的性質の改善を試みた.

\section{2. 実 験 方 法}

合金の作成には, 純度 $99.9 \% \mathrm{Ti}, 99.99 \% \mathrm{Fe}$ および $99.99 \% \mathrm{Al}$ の原料を用い, $\mathrm{Ti}-(3 \sim 6$ mass \% $) \mathrm{Fe}-(1 \sim 7$ mass \%) Al 合金 (以降 mass\%を省略して表記する)を作成し た. 溶解は非消耗型アーク溶解炉にて $\mathrm{Ar}$ 減圧雾囲気で約 5 $\mathrm{g}$ のボタンインゴットを作成した. 均質化のため 3 回反転 4 回の溶解を行った．また機械特性を調査するための合金作製 には浮遊溶解炬にて約 $700 \mathrm{~g}$ のインゴットを作成した。 それ ぞれインゴットからファインカッターにより約 $1 \mathrm{~mm}$ 厚の板 材を切り出し, 真空中 $1223 \sim 1323 \mathrm{~K}$ で $1 \mathrm{~h}$ の溶体化処理 後, 水水中で焼入れを行った。焼入れ材についてVickers 硬 さ試験, 光顕組織, SEM-EBSP, TEM 観察, 引張試験を行 った. 光顕組織はフッ酸 : 硝酸 : 水 $=1: 1: 10$ の腐食液を 用いて観察を行った。 TEM 試料は過塩素酸 : $n$-ブチルアル コール：メタノール $=1: 6: 10$ の電解液を用い, 液温 230 $\mathrm{K}$ にてッインジェット研磨により作成した。 また変形箇所 など局所領域の TEM 試料作成には FIB を用いた. 引張試 験はゲージ部 $10 \mathrm{~mm} \times 3 \mathrm{~mm} \times 0.8 \mathrm{~mm}$ の試験片を用い, 初 期ひずみ速度 $8.33 \times 10^{-4} \mathrm{~s}^{-1}$ にて破断まで行った。

\section{3. 実 験 結 果}

\section{1 硬さにおよばす $\mathrm{Al}$ 添加の影響}

Fig. 1 は $\mathrm{Ti}-x \mathrm{Fe}-1 \mathrm{Al}$ 合金の硬さにおよぼす $1 \% \mathrm{Al}$ 添加の 影響を示す．比較のため 2 元系 $\mathrm{Ti}-\mathrm{Fe}$ 合金の硬さの結果 ${ }^{9}$ も 示した. 2 元系では $4 \mathrm{Fe}$ で硬さのピーク (約 $530 \mathrm{Hv}$ )を示し, $\mathrm{Fe}$ の増加と共に軟化しているが，全組成にわたって高硬度
である。一方 $1 \%$ の $\mathrm{Al}$ 添加により，いずれも 2 元系合金よ り軟化することが分かった．特に $4 \mathrm{Fe}$ では約 $100 \mathrm{Hv}$ もの軟 化が認められた。

$\mathrm{Fe}$ 組成を $3 \%, 4 \%$ および $5 \%$ に固定し， $\mathrm{Al}$ 添加量を変え た合金の焼入れ硬さを Fig. 2 に示す. $\mathrm{Al}$ の増加に伴って軟 化したが， $4 \mathrm{Fe}$ が最も顕著であった。特に $\mathrm{Ti}-4 \mathrm{Fe}-(5 \sim 7)$ $\mathrm{Al}$ では 2 元系 Ti-4Fe より約 $200 \mathrm{Hv}$ もの軟化が認められた.

\section{2 焼入れ組織}

$\mathrm{Ti}-(3 \sim 6) \mathrm{Fe}-1 \mathrm{Al}$ の TEM 観察の結果，3Fe まではマル テンサイト $(\mathrm{M}$ 相 $)$ 組織で, $4 \mathrm{Fe}$ 以上では $\mathrm{M}$ 相は形成されず $\beta+\omega$ 組織であった.

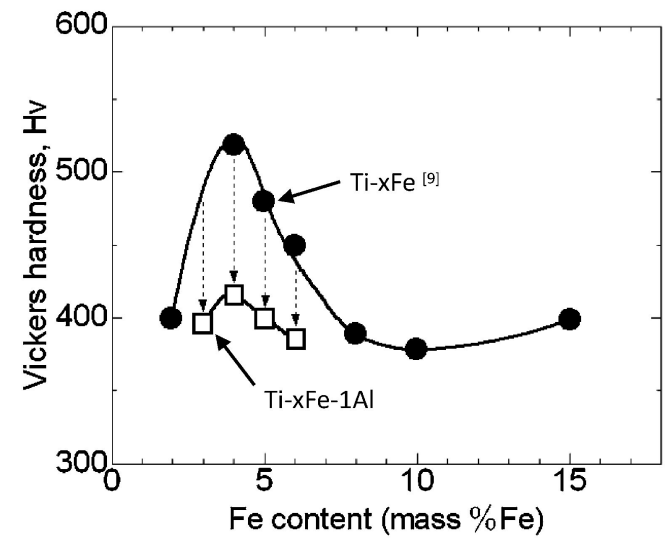

Fig. 1 Vickers hardness of $\mathrm{Ti}-x \mathrm{Fe}^{9)}$ and $\mathrm{Ti}-x \mathrm{Fe}-1 \mathrm{Al}$ quenched from $\beta$ field.

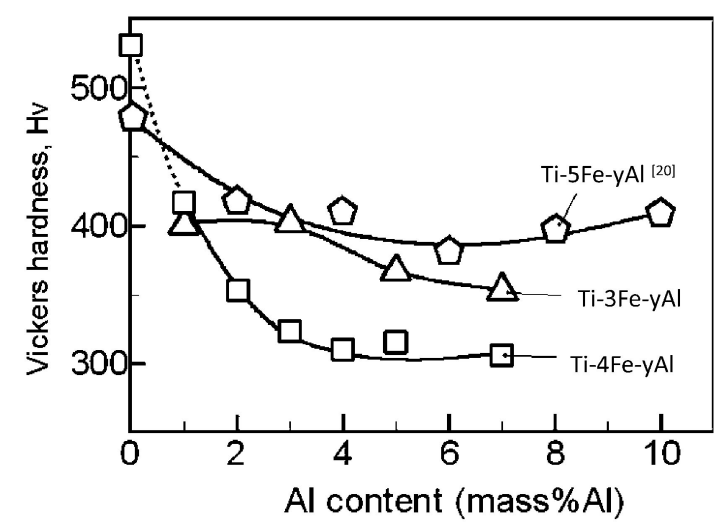

Fig. 2 Vickers hardness with $\mathrm{Al}$ content of $\mathrm{Ti}-(3-5) \mathrm{Fe}-y \mathrm{Al}$ alloys.
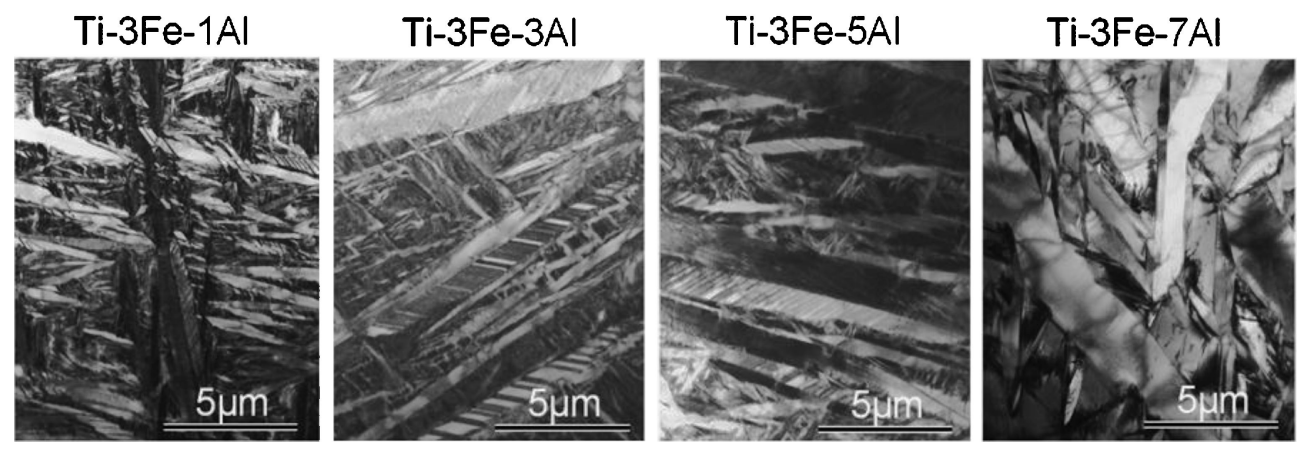

Fig. 3 TEM micrographs of quenched $\mathrm{Ti}-3 \mathrm{Fe}-y \mathrm{Al}$ alloys. 

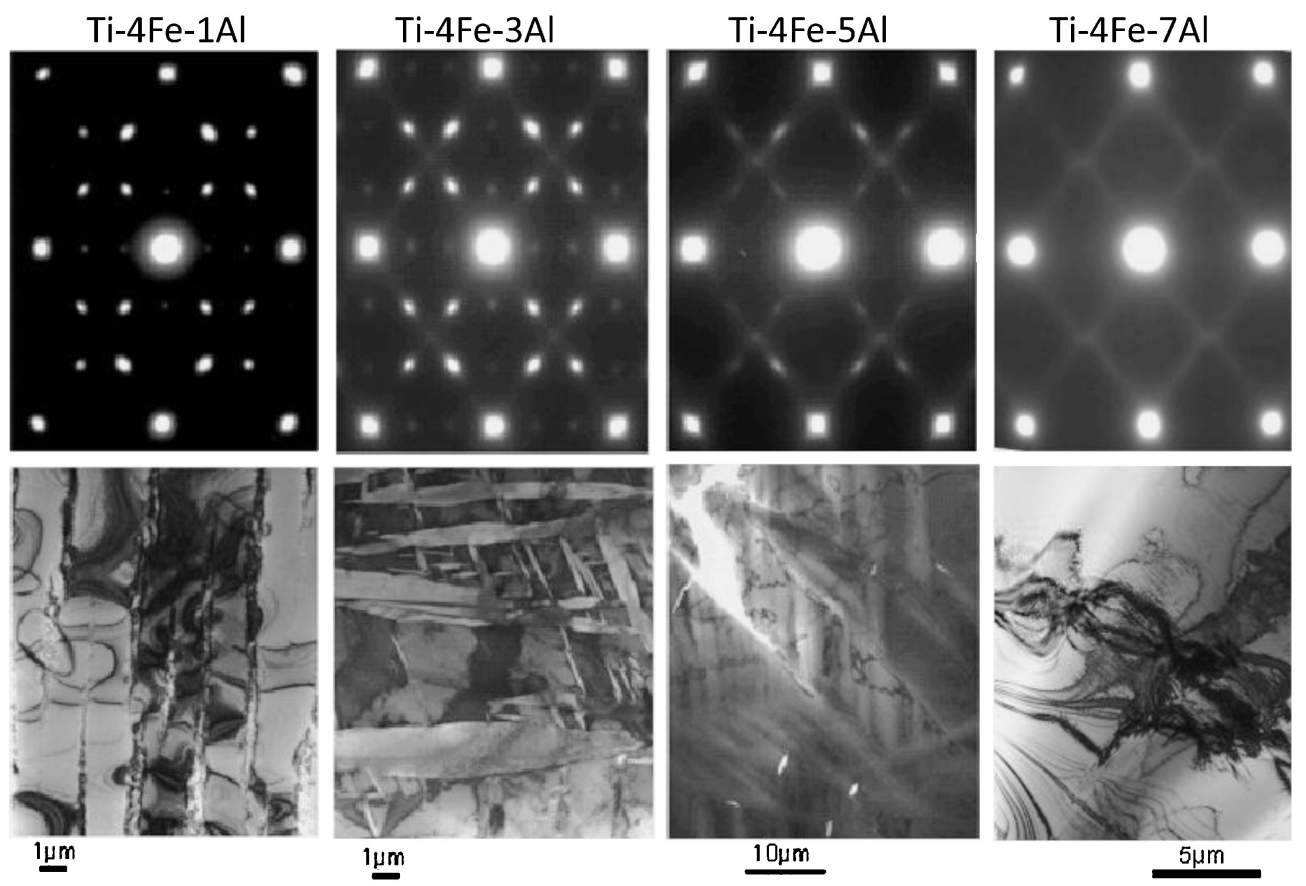

Fig. $4 \mathrm{SAD}$ patterns and TEM micrographs of quenched $\mathrm{Ti}-4 \mathrm{Fe}-y \mathrm{Al}$ alloys.

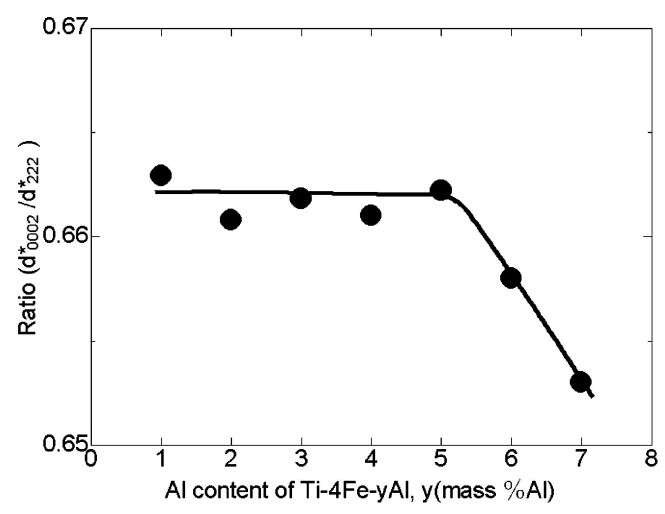

Fig. 5 Ratio of reciprocal distance $d^{*}{ }_{0002 \omega}$ to $d^{*}{ }_{222 \beta}$ in Ti-4Fe$y \mathrm{Al}$ alloys as a function of $\mathrm{Al}$ content.

Fig. 3 に Ti-3Fe- $y \mathrm{Al}$ の TEM 組織を示す. $7 \mathrm{Al}$ まで $\mathrm{Al}$ を 添加しても M 相組織のままであったが， $\mathrm{Al}$ の増加に伴って マルテンサイトの幅が大きくなる傾向があった.

Fig. 4 は $\mathrm{Ti}-4 \mathrm{Fe}-y \mathrm{Al}$ の TEM 組織を示す. $\mathrm{Al}$ 添加量が $2 \mathrm{Al}$ までは 2 元系とほとんど変わらず $\beta+\omega$ であったが， 3 $\sim 5 \mathrm{Al}$ では $\beta+\omega$ の他に $\mathrm{M}$ 相が形成された。 しかし $6 \mathrm{Al}$ 以 上の添加では $\mathrm{M}$ 相が消滅し, 再び $\beta+\omega$ 組織となった。こ の結果 $\mathrm{Ti}-4 \mathrm{Fe}-7 \mathrm{Al}$ の密度は $\beta$ 型 $\mathrm{Ti}$ 合金では最小の密度 $4.3 \times 10^{3} \mathrm{~kg} / \mathrm{m}^{3}$ となり， $\mathrm{Ti}-6 \mathrm{Al}-4 \mathrm{~V}$ 合金に匹敵するものと なった．母相の制限視野回折像 (SAD)では $\mathrm{Al}$ が増加するに 従って $\omega$ 相の反射が spot $\rightarrow$ diffuse に変化した.

$\mathrm{Ti}-4 \mathrm{Fe}-y \mathrm{Al}$ の $\{110\}_{\beta} \mathrm{SAD}$ パターンを用いて $\{332\}\langle 113\rangle$ 双晶形成の指針となる $d^{*}{ }_{0002 \omega} / d^{*}{ }_{222 \beta}$ を測定した結果を Fig. 5 に示す。 1 5Al までは約 0.662 を保ち変化はほとんど見 られなかったが，6A1 以上の合金では減少して 0.660 を下回 った.

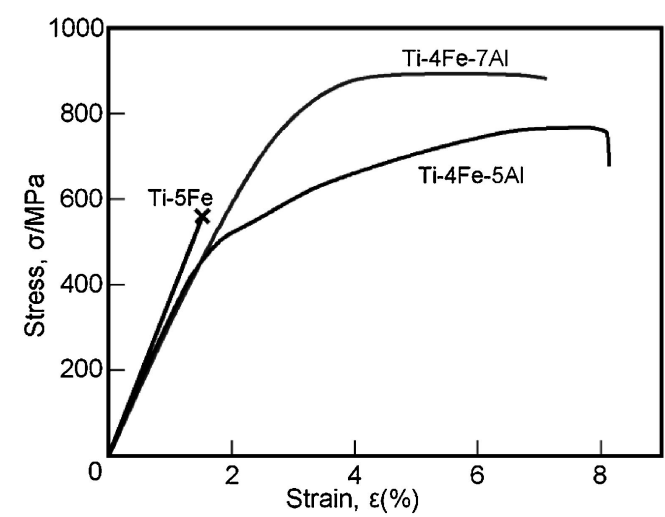

Fig. 6 Stress-strain curves of $\mathrm{Ti}-4 \mathrm{Fe}-5 \mathrm{Al}$ and $\mathrm{Ti}-4 \mathrm{Fe}-7 \mathrm{Al}$ compared to Ti-5Fe.

\section{$3.3 \quad \mathrm{Ti}-4 \mathrm{Fe}-y \mathrm{Al}$ の引張挙動と変形組織}

Fig. 6 は Ti-4Fe-5Al と Ti-4Fe-7Al の引張曲線を示す. 2 元系 $\mathrm{Ti}-5 \mathrm{Fe}\left(4 \mathrm{Fe}\right.$ も同様 $\left.{ }^{14}\right)$ )では $\omega$ 相のため脆性的で塑性 変形を示さないが，5Al 以上では延性を示すようになった。 $\mathrm{Ti}-4 \mathrm{Fe}-5 \mathrm{Al}$ では降伏応力が低く, その後加工硬化を示して いることから，Ti-Mo 合金での Ti-8Mo の引張挙動に近 い15,16)。一方， $\mathrm{Ti}-4 \mathrm{Fe}-7 \mathrm{Al}$ では降伏応力が高く，加工硬化 をあまり示さないことから，Ti-20Moの挙動17,18) に近いこ とが分かった。

引張破断後の試料から FIB により変形箇所の TEM 試料 をサンプリングし TEM 観察を行った．Fig. 7 は $\mathrm{Ti}-4 \mathrm{Fe}-$ $5 \mathrm{Al}$ のサンプリングを行った箇所の SEM, EBSP と TEM 組 織を示す．変形生成物は (a) に示すように，約 $4 \mu \mathrm{m}$ の幅を 有したバンド状の生成物であるが，(b)に示す IPF 解析の結 果，バンド状生成物の左側半分は母相と同じ方位関係を示し た。また (c)の Phase マップよりバンドの右半分は M 相 

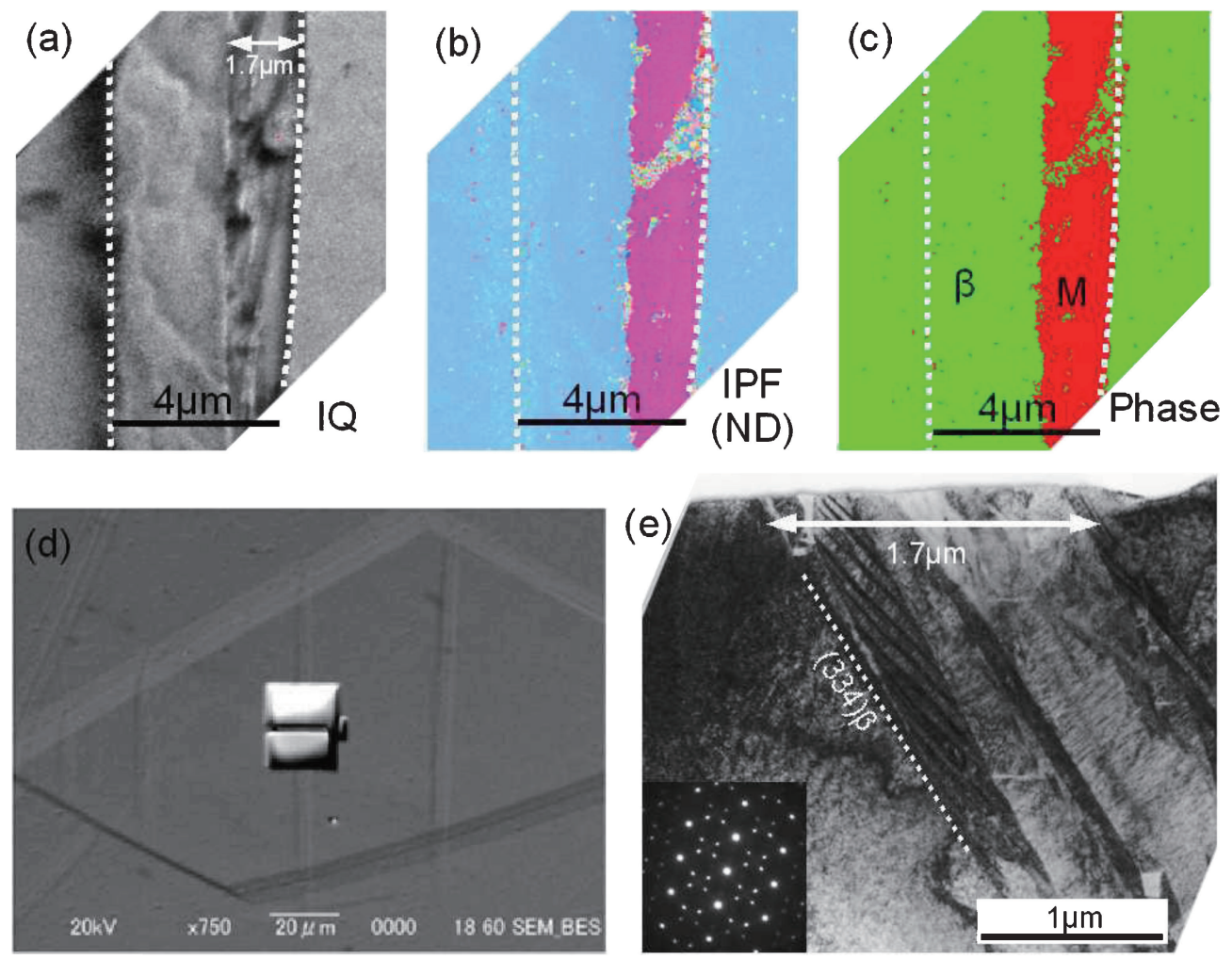

Fig. 7 EBSP, SEM, and TEM images of the deformation product of $\mathrm{Ti}-4 \mathrm{Fe}-5 \mathrm{Al}$. Image quality (IQ), inverse pole figure (IPF), and phase maps correspond to (a), (b), and (c), respectively. The dashed line shows the outline of the product. SEM image of the appearance of a sampling of TEM-foil by focused ion beam (FIB) method, (d). TEM image of the product and SAD pattern taken from the matrix, (e).
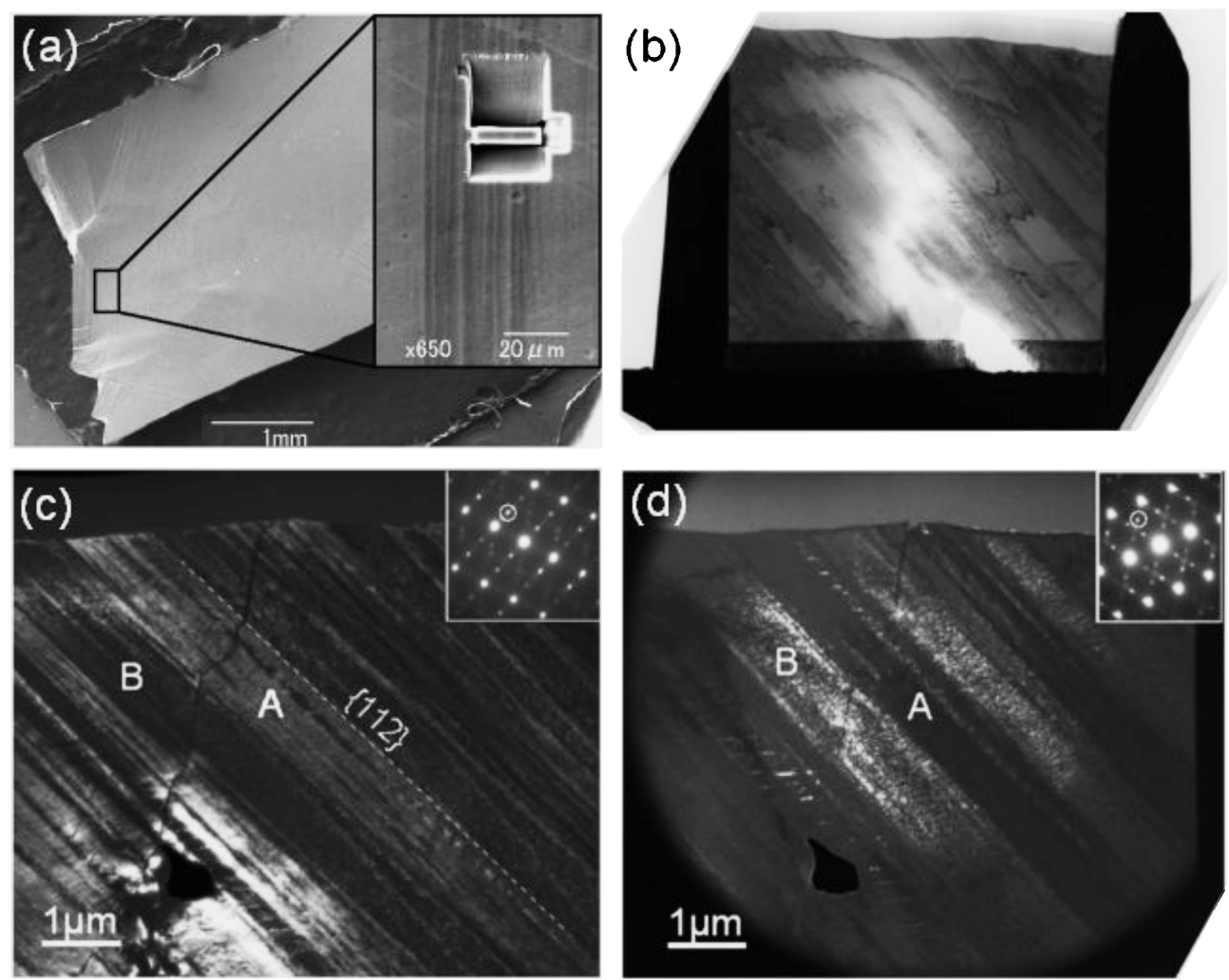

Fig. 8 SEM and TEM images of Ti-4Fe-7Al after deformation. Appearance of TEM foil sampling by FIB, (a). TEM image of deformation band at low magnification, (b). Dark field images using the $\omega$ spots circled in the SAD patterns, beam // $\langle 113\rangle_{\beta}$, (c) and $/ /\langle 110\rangle_{\beta}$, (d). 
で，左半分は母相と同じ構造を持つことが分かった．TEM 試料は (d)に示すようにバンド状生成物と直交する板材を FIB により切り出し薄片化した. その薄片をTEM 観察した 結果を(e)に示す．写真の点線より左側は (a)に抢けるバンド 状生成物の左半分に対応しており構造は $\beta+\omega$ であった。 た（b)の IPFより M 相は単一な方位を有する生成物として 解析されたが, TEM 観察からは M 相内部は幾つかのセク ションに分かれており，双晶などの欠陷も観察された。この 組織的な違いが EBSP 測定における分解能のためなのか, あるいは薄片化に伴って生じた $\mathrm{M}$ 相の構造緩和によるもの なのかは現時点では分からなかった。母相と $\mathrm{M}$ 相の境界は $\{334\}_{\beta}$ であり, $\mathrm{Ti}$ 合金で報告されている晶癖面 ${ }^{19)}$ と一致し た. Fig. 5 の結果より $\mathrm{Ti}-4 \mathrm{Fe}-5 \mathrm{Al}$ では $\{332\}\langle 113\rangle$ 双晶の形 成が期待されたが，本研究の範囲内では $\{332\}$ 双晶は認めら れなかった。

Fig. 8 は Ti-4Fe-7Al の変形材から TEM 試料のサンプリ ングの様子と TEM 観察の結果を示す。（a）の SEM 観察よ り，変形は粗大すべりによるものであることが分かった. TEM 試料はすべり線と直交するように薄片をサンプリング し，その低倍 TEM 写真を(b)に示す。変形はPlanner な $\{112\}\langle 111\rangle$ すべりであり，すべりが集中してバンドを形成 していることが分かった．（c）と（d）は同一箇所で試料を傾 斜し，それぞれバリアントの異なる $\omega$ 反射で撮影した暗視 野像である.未変形領域の Fig. 4 と比較すると変形帯での $\mathrm{SAD}$ パターンは $\omega$ 相の反射が spot 状に変化していること が分かった。 また (c)の領域 A で観察される $\omega$ 相は (d)では 観察されず，領域 Bでは逆転している。したがってすべり 帯では 4 つの $\omega$ バリアントが均等に spot 状の反射に変化し ているわけではなく, すべり帯によって特定の $\omega$ バリアン トが優先的に変化していることが分かった.

\section{4. 考察}

$\beta$ 共析型 $\mathrm{Ti}-\mathrm{Fe}$ 合金は $\beta$ 相が形成されても非常に硬いた め塑性加工はほとんど不可能であるが，Al 添加により軟化 し延性が発現することが分かった． Al 添加による軟化現象 は， $\mathrm{Al}$ が $\omega$ 相の形成を抑制するためであると説明されてい る20).しかし Fig. 2 で示したように $\omega$ 相が形成されない $\mathrm{Ti}-3 \mathrm{Fe}-y \mathrm{Al}$ でも $\mathrm{Al}$ 添加により軟化が認められた． TEM 組 織(Fig. 3) から考察すると $\mathrm{M}$ 相のサイズが $\mathrm{Al}$ 添加とともに 大きくなって抢り，これが $\mathrm{Ti}-3 \mathrm{Fe}-y \mathrm{Al}$ に抢ける軟化の原因 と考えられる。 また $\mathrm{Ti}-5 \mathrm{Fe}-y \mathrm{Al}$ と $\mathrm{Ti}-4 \mathrm{Fe}-y \mathrm{Al}$ の高 $\mathrm{Al}$ 組 成材で硬さの増加が少ないことから $\mathrm{Al}$ による固溶強化能は 低いと考えられる.

$\mathrm{Al}$ 添加は組織においても特異な現象を引き起こした．特 に $\mathrm{Ti}-4 \mathrm{Fe}-y \mathrm{Al}$ の焼入れ組織は $\mathrm{Al}$ の増加に伴って $\beta+\omega \rightarrow \beta$ $+\omega+\mathrm{M}$ 相 $\rightarrow \beta+\omega$ へと変遷した. $\mathrm{M}$ 相が生成されたこと は, $\mathrm{Al}$ が強力な $\alpha$ 安定化元素であるため $\mathrm{Ms}$ 点が室温以上 に上昇したことによると考えられる．しかしさらなる $\mathrm{Al}$ 添 加で $\mathrm{M}$ 相が消滅し再び $\beta$ 相が安定化されることは, $\mathrm{Al}$ が $\beta$ 安定化元素として作用することを意味している。この現象は これまでにも池田らが $\mathrm{Ti}-11 \mathrm{Mo}-y \mathrm{Al}^{21)}$ と $\mathrm{Ti}-7 \mathrm{Cr}-y \mathrm{Al}^{22)}$ で
報告しており, Ohyama と Nishimura は Ti-16V-y $\mathrm{Al}^{23)}$ で報 告している. 本研究の $\mathrm{Ti}-4 \mathrm{Fe}-y \mathrm{Al}$ も含めるといずれも $\beta$ 下 限組成に $\mathrm{Al}$ を添加した場合にこの現象が発現すると考えら れる.さらに池田らは Ti-5 $\mathrm{Fe}-y \mathrm{Al}^{20)}$ と $\mathrm{Ti}-20 \mathrm{~V}-y \mathrm{Al}^{24)}$ で同 様の実験を行っているが，基準合金が $\beta$ 下限組成より高い ため， $\mathrm{Al}$ 添加により $\mathrm{M}$ 相は形成されず $\mathrm{SAD}$ における $\omega$ 相 の反射が spot $\rightarrow$ diffuse へと変化したのみであった．これに ついて Ohyama らは $\mathrm{Al}$ 添加に伴う $\mathrm{Ms}$ 点の定性的な変化挙 動を提唱している ${ }^{23)}$. 彼らの解釈を用いれば，本研究にお ける現象も説明が可能である。 また Ti-3Fe- $y \mathrm{Al}$ で $\beta$ 相が形 成されなかったのは，基準合金の $\mathrm{Ti}-3 \mathrm{Fe} の \mathrm{Ms}$ 点が室温よ り高く, $\mathrm{Al}$ 添加により Ms 点がますます高温側に移行した ため $\mathrm{M}$ 相しか生成されなかったと考えられる。しかしなが ら $\mathrm{Al}$ が $\alpha$ 安定化として作用したり $\beta$ 安定化として作用する のかは不明なままである。

花田らはこれまで多くの $\beta$ 型 Ti 合金で合金組成に伴う $d^{*}{ }_{0002 \omega} / d^{*}{ }_{222 \beta}$ の変化を明らかにしている11-14) $\cdot d^{*}{ }_{0002 \omega} /$ $d^{*}{ }_{222 \beta}$ の比が減少することは， $\omega$ 相の反射が spot $\rightarrow$ diffuse になるとともに $\beta$ 相が安定化することを意味して抢り，Fig. 5 の結果も $\mathrm{Al}$ が $\beta$ 安定化元素として振る舞っていることを 支持している. また Fig. 6 の引張試験の結果から, Ti-4Fe5Al は Ti-8Mo と, Ti-4Fe-7 Al は Ti-20Mo とよく似た引 張挙動を示した.さらに Fig. 8 で示したように SAD に抢け る $\omega$ 相の反射が変形によって diffuse $\rightarrow$ spot へ変化してい ることは Ti-20Mo の特徵17)そのものであり, 変形挙動の観 点からも $\mathrm{Al}$ が $\beta$ 安定化元素として作用することを支持して いる.

以上のことから $\mathrm{Al}$ はある一定量以上の添加で $\beta$ 安定化元 素として振る舞うものと考えられるがそのメカニズムに関し ては今後の課題としたい.

\section{5. 結 論}

Ti-Fe 合金に Al を添加した合金について組織，機械特性 を調査した結果, 以下の知見が得られた。

(1) $\mathrm{Ti}-(3 \sim 6) \mathrm{Fe}$ に Al を 1\%添加することにより硬さは 大幅に減少し，特に Ti-4Fe では $100 \mathrm{Hv}$ もの軟化が見られ た。

（2） $\mathrm{Ti}-4 \mathrm{Fe}$ に $\mathrm{Al}$ を添加した $\mathrm{Ti}-4 \mathrm{Fe}-(5 \sim 7) \mathrm{Al}$ では $\mathrm{Ti}-$ $4 \mathrm{Fe}$ より $200 \mathrm{Hv}$ もの軟化が見られた.

(3) $\mathrm{Ti}-3 \mathrm{Fe}-y \mathrm{Al}$ の組織はいずれも $\mathrm{M}$ 相組織であったが， $\mathrm{Ti}-4 \mathrm{Fe}-y \mathrm{Al}$ では $\mathrm{Al}$ の添加量の増加に伴い, $\beta+\omega \rightarrow \beta+\omega$ $+\mathrm{M}$ 相 $\rightarrow \beta+\omega$ へと変遷した. 特に $\mathrm{Ti}-4 \mathrm{Fe}-7 \mathrm{Al}$ の密度は $\beta$ 型 $\mathrm{Ti}$ 合金で最小の $4.3 \times 10^{3} \mathrm{~kg} / \mathrm{m}^{3}$ を有する.

(4) $\mathrm{Ti}-4 \mathrm{Fe}-y \mathrm{Al}$ の $\mathrm{SAD}$ に抢ける軸比 $\left(d^{*}{ }_{0002 \omega} / d^{*}{ }_{222 \beta}\right)$ 変 化は 1 5Al までは一定值で $6 \mathrm{Al}$ 以上で低下した。

(5) $\mathrm{Ti}-4 \mathrm{Fe}-5 \mathrm{Al}$ と $\mathrm{Ti}-4 \mathrm{Fe}-7 \mathrm{Al}$ の引張試験では延性が認 められ， $\mathrm{Ti}-4 \mathrm{Fe}-5 \mathrm{Al}$ は $\mathrm{Ti}-8 \mathrm{Mo}$ の引張挙動に類似してお り，加工誘起 $\mathrm{M}$ 相が観察された。一方， $\mathrm{Ti}-4 \mathrm{Fe}-7 \mathrm{Al}$ では

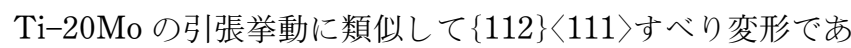
った。またすべり帯の SAD では特定の $\omega$ バリアントが diffuse $\rightarrow$ spotへと変化した. 
(6) $\beta$ 下限組成の合金に $\mathrm{Al}$ を添加すると一定量以上の添 加で $\mathrm{Al}$ は $\beta$ 安定化元素として振る舞う.

文献

1) H. Matsumoto, S. Watanabe and S. Hanada: Mater. Trans. 46 (2005) 1070-1078

2) N. Sakaguchi, M. Niinomi, T. Akahori, J. Takeda and H. Toda: J. Japan Inst. Metals 68 (2004) 1076-1082.

3) H. Y. Kim, Y. Ohmatsu, J. I. Kim, H. Hosoda and S. Miyazaki: Mater. Trans. 45(2004) 1090-1095.

4) H. Y. Kim, T. Sasaki, K. Okutsu, J. I. Kim, T. Inamura, H. Hosoda and S. Miyazaki: Acta Mater. 54(2006) 423-433.

5) T. Maeshima and M. Nishida: Mater. Trans. 45(2004) 10961100.

6) T. Maeshima and M. Nishida: Mater. Trans. 45(2004) 11011105.

7) B. Gunawarman, M. Niinomi, T. Akahori, T. Souma, M. Ikeda and H. Toda: Mater. Sci. Eng. C 25 (2005) 304-311.

8) A. Bhattacharjee, P. Ghosal, A. K. Gogia, S. Bhargava and S. V. Kamata: Mater. Sci. Eng. A 452-453(2007) 219-227.

9) S. Komatsu, M. Ikeda, T. Sugimoto, K. Kamei and K. Inoue: J. Japan Inst. Metals 55(1991) 491-496.

10) Y. Takemoto, M. Hida, E. Sukedai and A. Sakakibara: J. Japan Inst. Metals 53 (1989) 1004-1012.
11) S. Hanad, M. Ozeki and O. Izumi: Metall. Trans. A 16(1985) 789-795.

12) S. Hanada and O. Izumi: J. Mater. Sci. 21(1986) 4131-4139.

13) S. Hanad and O. Izumi: Metall. Trans. A 17 (1986) 1409-1420.

14) S. Hanada, T. Yoshio and O. Izumi: J. Mater. Sci. 21(1986) 866-870.

15) Y. Mantani, Y. Takemoto, M. Hida, A. Sakakibara and M. Tajima: Proc. the $3^{\text {rd }}$ Int. Conf. on Advanced Materials Processing, (2004) pp. 516-520.

16) Y. Takemoto, A. Sakakibara and T. Senuma: Ti-2007 Science and Technology (Proc. the 11th World Conf. on Titanium, JIMIC5), (the Japan Inst. Metals, 2007) pp. 539-542.

17) Y. Takemoto, I. Shimizu, A. Sakakibara, M. Hida and Y. Mantani: Mater. Trans. 45(2004) 1571-1576.

18) Y. Takemoto, I. Shimizu, A. Sakakibara and T. Senuma: J. Japan Inst. Metals 70(2006) 110-113.

19) P. Gaunt and J. W. Christian: Acta Metall. 7(1959) 534-543.

20) M. Ikeda, S. Komatsu, T. Sugimoto, K. Kamei and K. Inoue: Tetsu-to-Hagane 80 (1994) 866-870.

21) M. Ikeda, S. Komatsu and T. Sugimoto: J. JILM 50 (2000) 435440.

22) M. Ikeda, D. Sugano, S. Masuda and M. Ogawa: Mater. Trans. 46 (2005) 1604-1609.

23) H. Ohyama and T. Nishimura: Titanium '95, Science and Technology, ed. by P. A. Blenkinsop et al., (The Institute of Materials, London, 1996) 2273-2280.

24) M. Ikeda, S. Komatsu, T. Sugimoto and K. Kamei: J. JILM 42 (1992) 622-626. 